\title{
ON THE DISTRIBUTION OF VARIOUS METACERCARIAE OF TREMATODES WITHIN THE FISH BODY
}

\author{
YOSHITAKA KOMIYA AND KATSUKO MURASE \\ The National Institute of Health, Tokyo, Japan \\ (Received: January 17th, 1952)
}

In the orient, particulary in Japan and China, numerous species of fishes are found not seldom to be the second intermediate hosts of various species of trematodes. When the prevalence of a certain species of such trematodes is to be surveyed, one of the shortest ways is to examine the infestation of its metacercaria on certain species of fish. Among such species of fish, Pseudorasbora and Sarcocheilichthys are the most convenient ones for the purpose, because these are the most common fish in such areas and are usually found infected with almost all species of metacercariae. However, the distribution of metacercariae within fish body varies as the part of fish body varies. The porpose of this work is to determine as to which part of fish body is preferred by metacercariae to harbour mostly.

\section{MATERIALS AND METHODS}

As materials, each fifteen specimens of Pseudorasbora parva and Sarcocheilichthys sinensis were adopted. They were obtained from a Chinese market in Shanghai and were $7-8 \mathrm{~cm}$ in their body length.

The fish body was divided first into five portions: head, gills, scales, fins and muscles including adjacent subcutaneous tissues. Among them, fins and muscles are, as seen in Fig. 1, again subdivided into the following: fins (dorsal fin, tail fin and others), and muscles (muscles adjacent to tail, muscles adjacent to dorsal fin, muscles adjacent to breast fin, muscles adjacent to head and the rest). For collecting metacercariae from fish body, the digestion method was employed. This method was proved to be capable of collecting more than $60 \%$ of all matacercariae infesting in fish body (Komiya et al. 1951). All metacercariae thus collected were identified and then counted under dissecting microscope. 


\section{RESULTS}

1. The total number of all species of metacercariae infested in fish body (Table 1, 2).

Average number of the total metacercariae of all species infesting per one individual Pseudorasbora was 6,424.3, the highest number being 10,257 and the lowest 163, whereas that infesting per one individual Sarcocheilichthys was 941.1, the highest being 3,438 and the lowest 108 . Among various parts of infestation in Pseudorasbora, muscles showed the highest percentage, $69 \%$ of the total number of metacercariae, which were followed with head (12\%) and fin (10.5\%). In Sarcocheilichthys, muscles harboured $55 \%$, head $23.7 \%$, and fin $15.5 \%$ of the total number of metacercariae.

2. Number of each species of metacercariae infested in fish body.

The species of metacercariae found in both species of fish were as follows: Clonorchis sinensis, Cyathocotyle orientalis, Echinochasmus japonicus, Exorchis oviformis, Metacercaria hasegawai a, Prosorhynchus echinatus and Metacercaria shinjoi. Distribution of these metacercariae in each species of fish body was as follows:

a. In Pseudorasbora: Exorchis oviformis showed the highest incidence. Average number infesting per one fish body was 3,073, about $50 \%$ of all metacercariae, the highest number in one fish amounting to 6,392: the average number of Cyathocotyle orientalis was 2468.8 per one

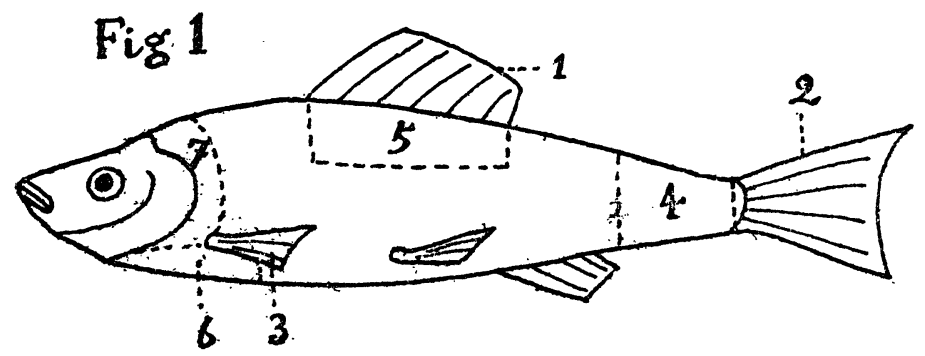

Fig. 1

Body of fish showing the respective part examined. 1. dorsal fin, 2. tail fin, 3. breast fin, 4. muscles adjucent to tail, 5. muscles adjucent to dorsal fin, 6. muscles adjucent to breast fin, 7. muscles adjucent to head. 
fish, about $38 \%$ of all metacercairae and the highest incidence in one fish amounted to 8,595: the incidence of Clonorchis sinensis was relatively small, the average number per one fish being about $24 \%$ of all metacercaria, the highest incidence in one fish amounting to 206.

b. In Sarcocheilichthys: Here, the incidence of Clonorchis showed the highest among all species of metacercariae, its avarage number per one fish was 695.7 , about $74 \%$ of all metacercariae, and its highest incidence amounted to 2,888 in one fish; the average number of Exorchis per one fish was about $19 \%$ of all metacercariae.

3. Distribution of various metacercariae within the fish body.

a. Clonorchis sinensis. The majority of the larva of this species was infesting in muscles and adjacent subcutaneous tissues; in Pseudorasbora, about $83 \%$, and in Sarcocheilichthys, about $63 \%$ of the total number collected were found in muscles. But the incidence in head showed relatively a large number, $7 \%$ in the former and $22 \%$ in the latter. As compared with the above mentioned parts; fins, scales and gills, showed remarkably lower infestation.

b. Cyathocotyle orientalis. This species of metacercaria showed also the highest incidence in muscles; in Pseudorasbora, about $80 \%$ of the total number. The percentage infested in head was also relatively high; about $11 \%$ of the total number. The incidence in fins, scales and gills was low as that of Clonorchis. In Sarcocheilichthys we were not able to discuss its distribution as its total number was too small.

c. Echinochasmus japonicus. As already known, this was found exculsively in gills.

d. Exorchis oviformis. In Pseudorasbora, about $69 \%$ of the total number were found infested in muscles, about $15 \%$ in head and $14 \%$ in fins, whereas, in Sarcocheilichthys, about 30\% in muscles, $25 \%$ in head, and $25 \%$ in gills, thus in this fish, a relatively high incidence was observed in head and gills as compared with the former.

e. Metacercaria hasegawai a. Distribution of this metacercaria showed the same pattern as that of Exorchis; in Pseudorasbora, about $69 \%$ of the total number were found infested in muscles, $17 \%$ in head, $12 \%$ in fins, whereas in Sarcocheilichthys, about 30\% in muscles, $32 \%$ in head and $30 \%$ in fins.

f. This is a metacercaria of Cercaria shinjoi, an echinostomous one (Komiya and Tajimi, 1941). It was found infested only in Sarcocheilich- 
thys. Its incidence in various parts of fish body was as follows: about $30 \%$ of the total number in muscles, $26 \%$ in head and $29 \%$ in scales.

g. Metorchis orientalis. The incidence of this metacercaria was found particulary in large number in Pseudorasbora. Its distribution in various parts of fish body was about the same as that of Clonorchis; about $75 \%$ of the total number in muscles, $17 \%$ in heads and the rest in other parts.

4. Distribution of various metacercariae within muscles.

As above mentioned, the majority of all metacercariae were found mainly in muscles except the larva of Echinochasmus. Tables 7 and 8 show the distribution of each species of metacercariae within muscles of various parts. As seen in these tables, the majority of the total number of all species of metacercariae were found in "the rest" muscles and those infesting in muscles adjacent to tail were only $10 \%$ in Pseudorasbora and 18\% in Sarcocheilichthys of the total number. However, when the number of metacercariae per one gram of muscles of each part was calculated, the percentage of metacercariae infesting in muscles adjacent to tail, head and breast and dorsal fins was proved to be relatively high, as shown in Tables 9 and 10 .

The distribution of principal species of metacercariae within muscles of each part was as follows:

a. Clonorchis sinensis. In Pseudorasbora, muscles adjacent to breast fin showed the highest incidence, about $39 \%$ of the total number, and those adjacent to tail about $24 \%$ and to dorsal fin about $20 \%$. In Sarcocheilichthys, muscles adjacent to head showed the highest incidence, about $31 \%$, and those adjacent to tail about $20 \%$ and to dorsal fin $18 \%$.

b. Cyathocotybe orientalis. In Pseudorasbora, muscles adjacent to tail showed the highest incidence, about 32\%, and those adjacent to breast fin $21 \%$ and adjacent to head $20 \%$ and to dorsal fin 18\%. In Sarcocheilichthys, as the infesting number of metacercariae was small, the incidence is not referred to in this paper.

c. Exorchis oviformis. In Pseudorasbora, about $23 \%$ of the total number were found in muscles adjacent to tail, whereas the percentage of metacercariae found in those adjacent to dorsal and breast fins, adjacent to head were about the same (18 to 21\%). In Sarcocheilichthys, those found in muscles adjacent to breast fin showed the highest per- 
centage, $38 \%$, which was followed by muscles adjacent to head (24\%).

d. Metacercaria hasegawai a. In Pseudorasbora, muscles adjacent to head showed the highest percentage, about $27 \%$, which was followed by those adjacent to head (26\%). In Sarchocheilichthys, as the number of infesting metacercariae was too small, nothing is referred to in this paper.

e. Metorchis orientalis. In Pseudorasbora, muscles adjacent to tail showed the highest incidence, about $27 \%$, which was followed by muscles adjacent to head (26\%). In Sarcocheilichthys as, the infesting number of metacercariae was too small, nothing is referred to in this paper.

\section{DISCUSSION AND SAMMARY}

a. Clonorchis infection in two species of fish.

Previously one of the authors (Komiya and Tajimi, 1940) reported that in Shanghai area in China, the fish harbouring the largest number of Clonorchis was Sarcocheilichys nigripennis. At that time it was also proved that Pseudorasbora was not typical second intermediate host of Clonorchis in that area, but was of more significance as that of Metorchis. Here we proved that Sarcocheilichtys sinensis was more important as a second intermediate host of Clonorchis than Pseudorasbora, of which incidence of harbouring Clonorchis metacercariae had been 1 ow $(0.4 \%$ of the total number of all species of metacercariae). On the other hand, Hisayama (1938) reported that in Pseudorasbora in Okayama prefecture in Japan, the incidence of [Clonorchis had been very high $76 \%$ of the total number of all species of metacercariae). As to the reason why such a difference comes to manifest between the same species of fish in these two areas, sufficient materials are not available at present.

b. Route of Clonorchis infection to fish.

The metacercariae of Clonorchis sinensis, Exorchis oviformis and Cyathocotyle orientalis were found mainly in muscles and their adjacent connective tissues but also found in scales, gills and fins in small number. It is worth to mention that these metacercariae were found in the soft tissues in head relatively large in number. For instance, Clonorchis were found $7.1 \%$ and $21.6 \%$ of the total number of all metacercariae in both species of fish in our present results and $7 \%$ and $19.9 \%$ in those of the previous workers, as shown in Table 11. Vogel (1934) observed that the cercaria of Opistorchis felineus entering into fish body mainly along its 
fins and encysted in muscles and adjacent connective tissues. The experimental infection of fish with Clonorchis made by the senior author (1940) also prove that the main route of Clonorchis infection to fish was that along fins. However, the relatively high incidence of Clonorchis and other metacercariae in the soft tissues of head can hardly be explained by above mentioned route of infection. The authors think it rather natural that such an infection was caused by adhesion and penetration by the cercariae through the mucosa of the oral cavity when the cercaria was sucked into the mouth of the fish with water by the respiration of the latter. In other words, the relatively high incidence of Clonorchis in the soft tissues of head suggests that the aspiration act of fish should be the secondary route of its infection.

c. Effective method of examining Clonorchis metacercaria from fish body.

The various species of metacercariae infesting fish body, particularly that of Clonorchis, were proved to habour relatively in high percentage in muscles adjacent to fins, which fact gives us the facility of examining such metacercariae from fish body. The practical procedure of the method is as follows:

Take two or three grams of muscles adjacent to tail and head and breast fin, press them thin between two slide glasses and examine them under dissecting microscope. In this way, the infesting metacercariae can be easily discovered.

\section{REFERENCE}

1) Hasegawa, T.: On the encysted metacercariae infested in Pseudorasbora parva (Temminck and Schlegel). Okayama Medical Journ. 47. 1397, 1935. (in Japanese).

2) Hisayama, M.: The seasonal variation of trematodes larvae in their first and second intermediate hosts. Okayama Medical Journ. 50. 327, 1938. (in Japanese).

3) Hsü, H. E.: Studies on cercain Iproblems of Clonorchis sinensis. VII Further advance in the study of the life cycle of Clonorchis sinensis. Chinese Med. Journ. 55. 542, 1939.

4) Komiya, Y. and Tajimi, T.: Study on Clonorchis sinensis in the district of Shanghai. 5. The cercaria and metacercaria of Clonorchis sinensis with special reference of their excretory system. Journ. Shanghai Science Inst. Section IV. (5) 91. 1940. a.

5) Komiya, Y. and Tajimi, T.: Study on Clonorchis sinensis in the district of Shanghai. 6. The life cycle of Exorchis oviformis, with special reference 
of the similarity of its larval forms to that of Clonorchis sinensis. Journ. Shanghai Science Inst. Sect. IV (5), 109. 1940, b.

6) Komiya, Y. and Tajimi, T.: Metacercarie from Chinese Pseudorasbora parva Temminck and Schlegel with special reference to their excretory system. Journ. Shanghai Science Inst. N.S. 1. (1), 69. 1941.

7) Komiya, Y. and Murase, K.: Efficacy of digestion method for collecting metacercariae form the fish body. Jap. Med. Journ. 4.(1), 43. 1951.

8) Vogel, H.: Der Entwicklung von Opisthorchis felineus (Riv.) nebst Bemerkungen uber die Systematik und Epidemiologie. Soologica. 33. Ht. 86. Stuttgart. 


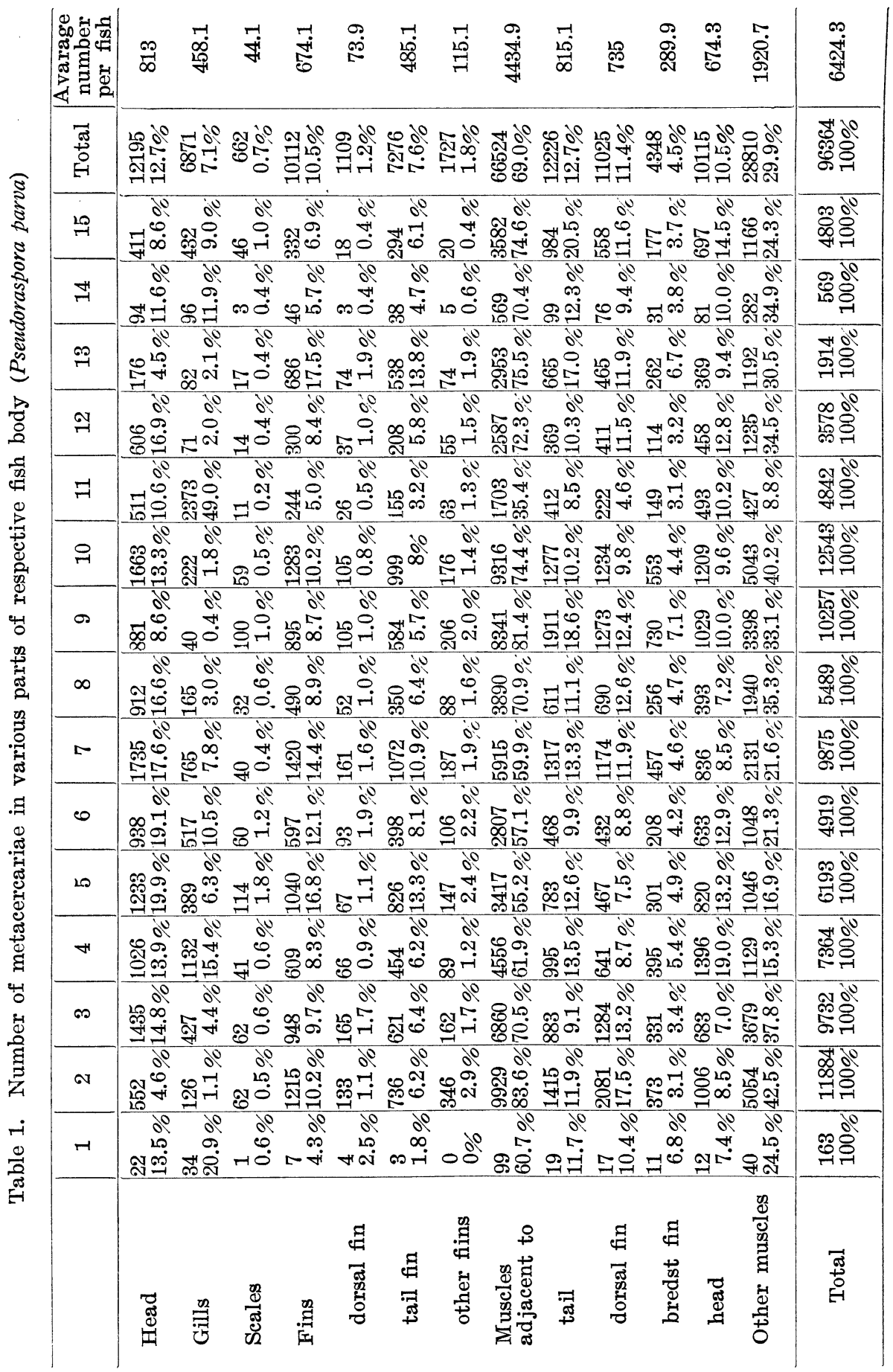




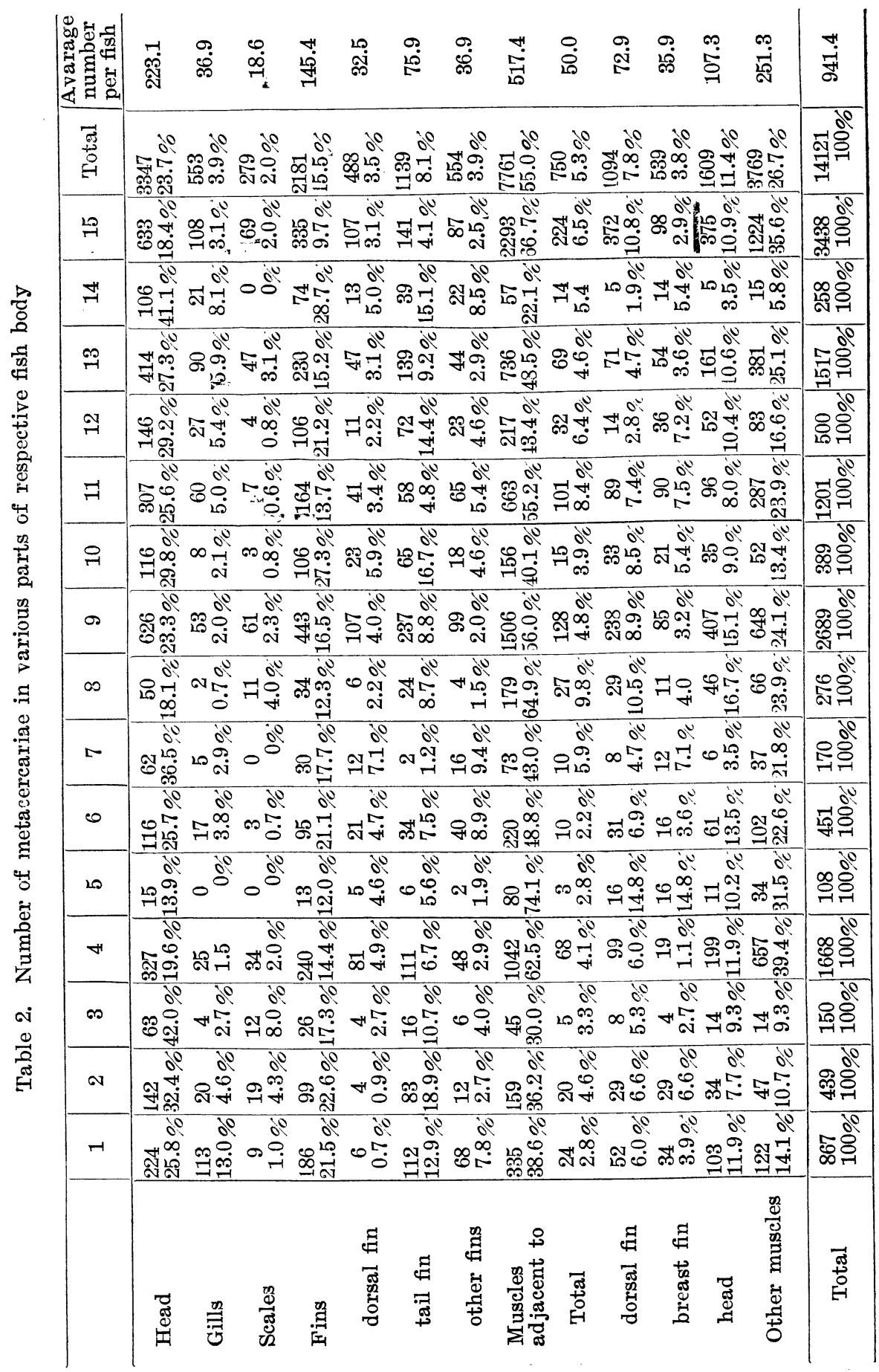




\begin{tabular}{|c|c|c|c|c|c|c|c|c|c|c|}
\hline \multirow{5}{*}{ 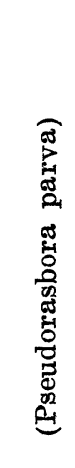 } & 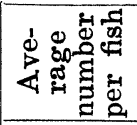 & $\stackrel{\infty}{\mathbb{H}}$ & 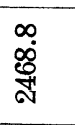 & $\begin{array}{l}\text { क् } \\
\text { ळू. }\end{array}$ & $\begin{array}{l}\stackrel{\circ}{0} \\
\stackrel{\leftrightarrow}{5} \\
\stackrel{0}{\circ}\end{array}$ & $\stackrel{\infty}{\stackrel{\leftrightarrow}{\Phi}}$ & $\begin{array}{l}\ddot{\infty} \\
\ddot{\circ} \\
\ddot{\sigma}\end{array}$ & -10 & $\stackrel{10}{0}$ & ঙ̊. \\
\hline & 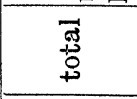 & 륨 & 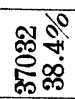 & 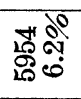 & 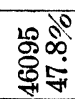 & 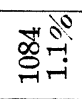 & 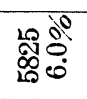 & No do & $\infty \stackrel{0}{0}$ & 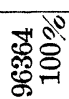 \\
\hline & $\stackrel{20}{-19}$ & 0 gी & 대 & ఖ্ণ & r & 08 & 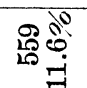 & og & $0 g^{\circ}$ & 。̊ \\
\hline & $\underset{ت}{ت}$ & od & 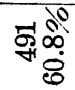 & कี & Wd & $-1 \frac{0}{5 !}$ & $5 \cos _{\infty}^{\infty}$ & $08^{\circ}$ & 08 & क्ळ \\
\hline & $\stackrel{\mathscr{r}}{\sim}$ & N & 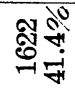 & 5. & 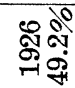 & ฉ̊d & 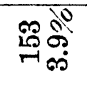 & $\begin{array}{l}-10 \\
\stackrel{0}{0} \\
0\end{array}$ & 080 & 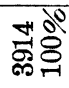 \\
\hline & $\stackrel{\leftrightarrow}{\sim}$ & $00^{\circ}$ & नำ & $8 \frac{d}{4}$ & 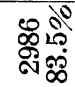 & $\begin{array}{r}-100 \\
\text { है } \\
0\end{array}$ & S: & $\circ d^{\circ}$ & $08^{\circ}$ & 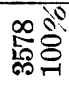 \\
\hline & $\Rightarrow$ & $\circ g^{\circ}$ & ๙ & 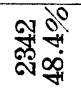 & 융 & ผู ถู & 냉 & $0 g^{\circ}$ & rd & హ్ర \\
\hline & 유 & దิ & 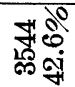 & فำ & 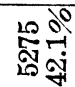 & सt & क⿺辶 & $0 g^{\circ}$ & 080 & : \\
\hline & 0 & $\nabla \frac{10}{0}$ & $\begin{array}{l}1200 \\
180 \\
1000 \\
\infty \\
\infty\end{array}$ & 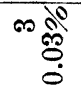 & 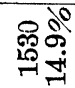 & a do & 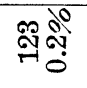 & 0 हू & 08 & 동ㅇㅇㅇ \\
\hline & $\infty$ & og & 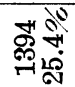 & m & 댐ำ & $\infty 20$ & $\begin{array}{l}\text { ㄷํㅇ } \\
\text { สे }\end{array}$ & $0 g^{\circ}$ & 089 & 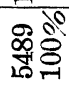 \\
\hline & 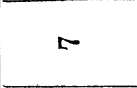 & 유: & 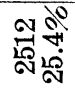 & 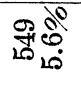 & 웜 & $\infty \infty^{\infty}$ & लै & $0 g^{\circ}$ & 0 o & 12:00 \\
\hline & 0 & ' & E. & $\underset{\forall}{\mathscr{\alpha}} \underset{\infty}{d 0}$ & जी & 赵 & 我 & $\begin{array}{r}-\mathrm{d} \\
\stackrel{0}{0}\end{array}$ & a do & 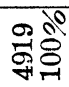 \\
\hline & م2 & $08^{\circ}$ & 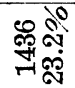 & $\begin{array}{l}00 \\
\text { do } \\
\text { जै }\end{array}$ & $\begin{array}{l}\text { कू } \\
\text { अุष }\end{array}$ & 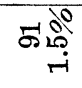 & 곡 & $08^{\circ}$ & 0 ge & 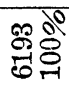 \\
\hline & + & 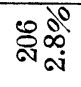 & 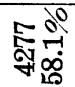 & 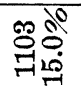 & 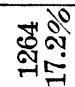 & न $\frac{d 0}{3}$ & 을 $\frac{d 0}{0}$ & $08^{\circ}$ & $08^{\circ}$ & స్థై \\
\hline & $\infty$ & og & 룽 & 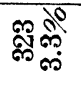 & $\begin{array}{l}000 \\
1800 \\
30\end{array}$ & 580 & 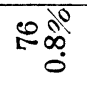 & $0 g^{\circ}$ & r- $\frac{10}{5}$ & 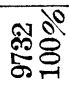 \\
\hline & N & ro & 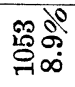 & $\exists \frac{d}{0}$ & 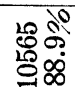 & $=7 \frac{d}{0}$ & 吕 & $00^{\circ}$ & $08^{\circ}$ & 莺 \\
\hline & -1 & $\begin{array}{l}1000 \\
\text { बू } \\
\text { के }\end{array}$ & 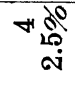 & ล2 & దढ़े & 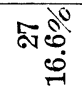 & 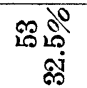 & o de & 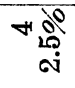 & : \\
\hline & 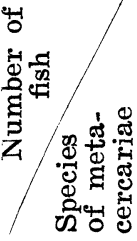 & 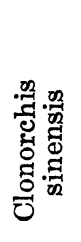 & 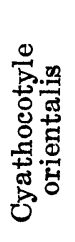 & 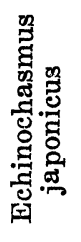 & 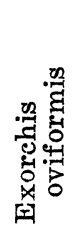 & 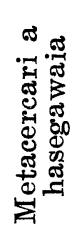 & 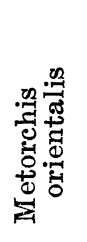 & 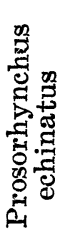 & 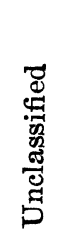 & 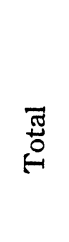 \\
\hline
\end{tabular}




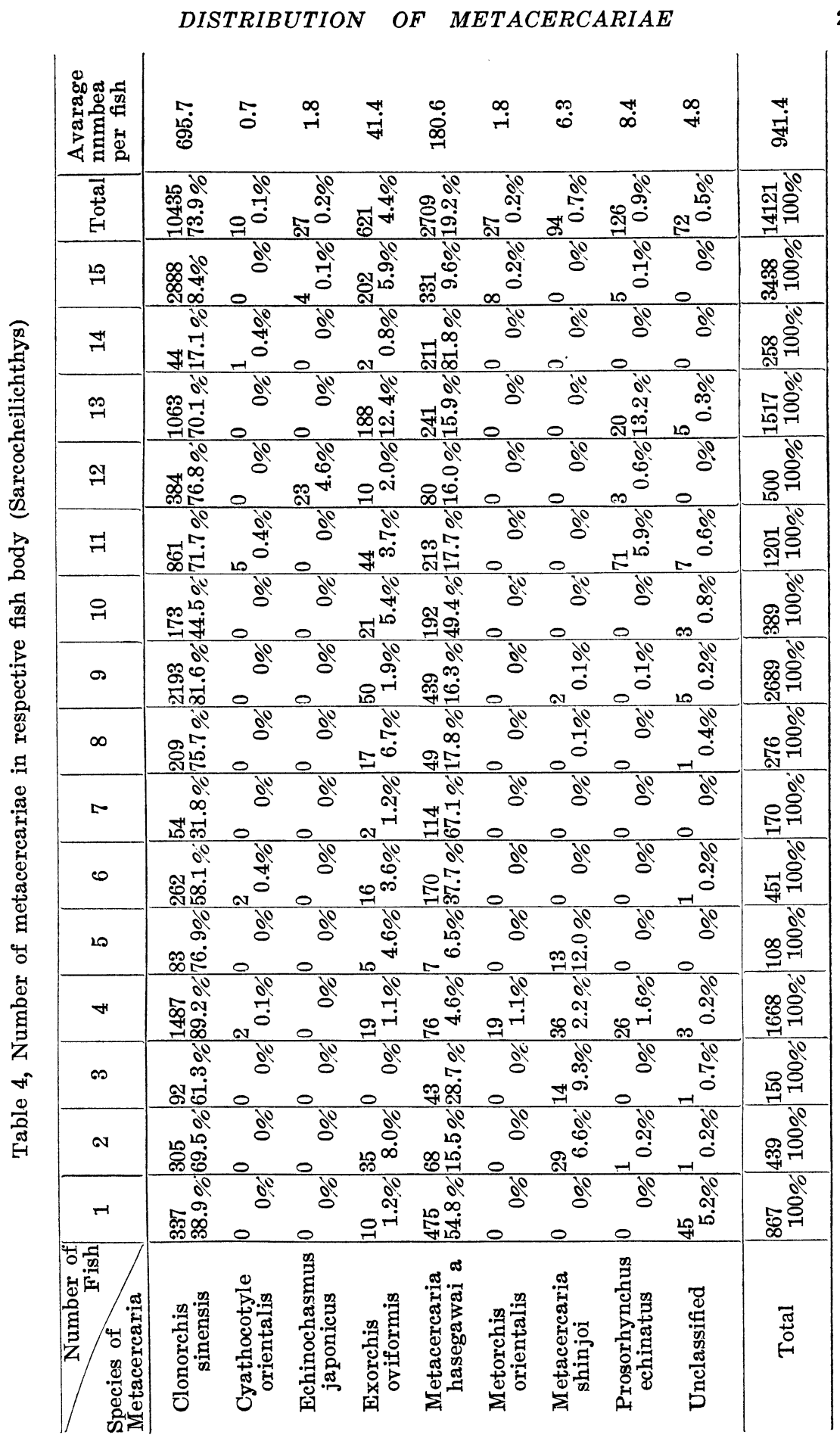




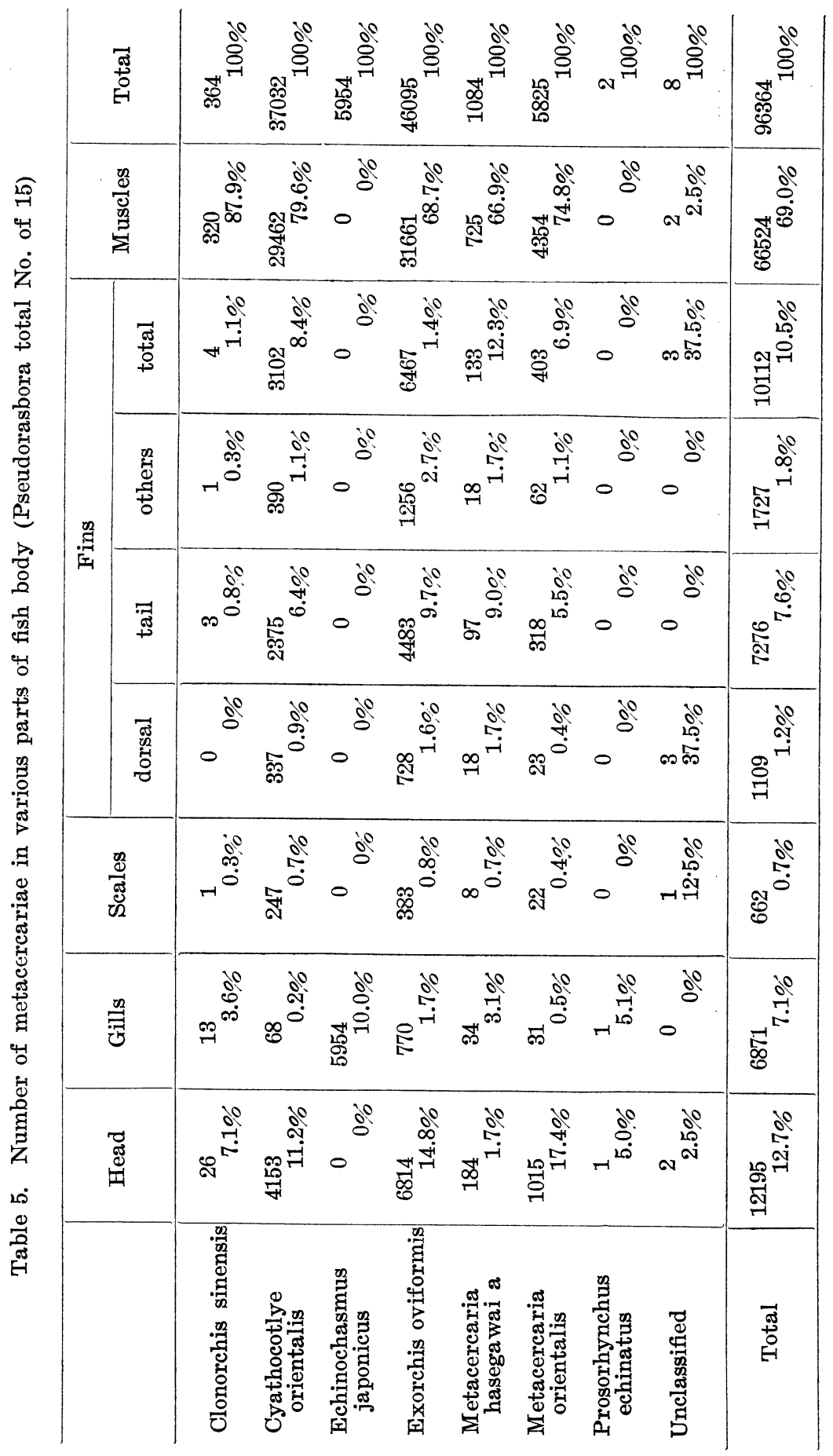




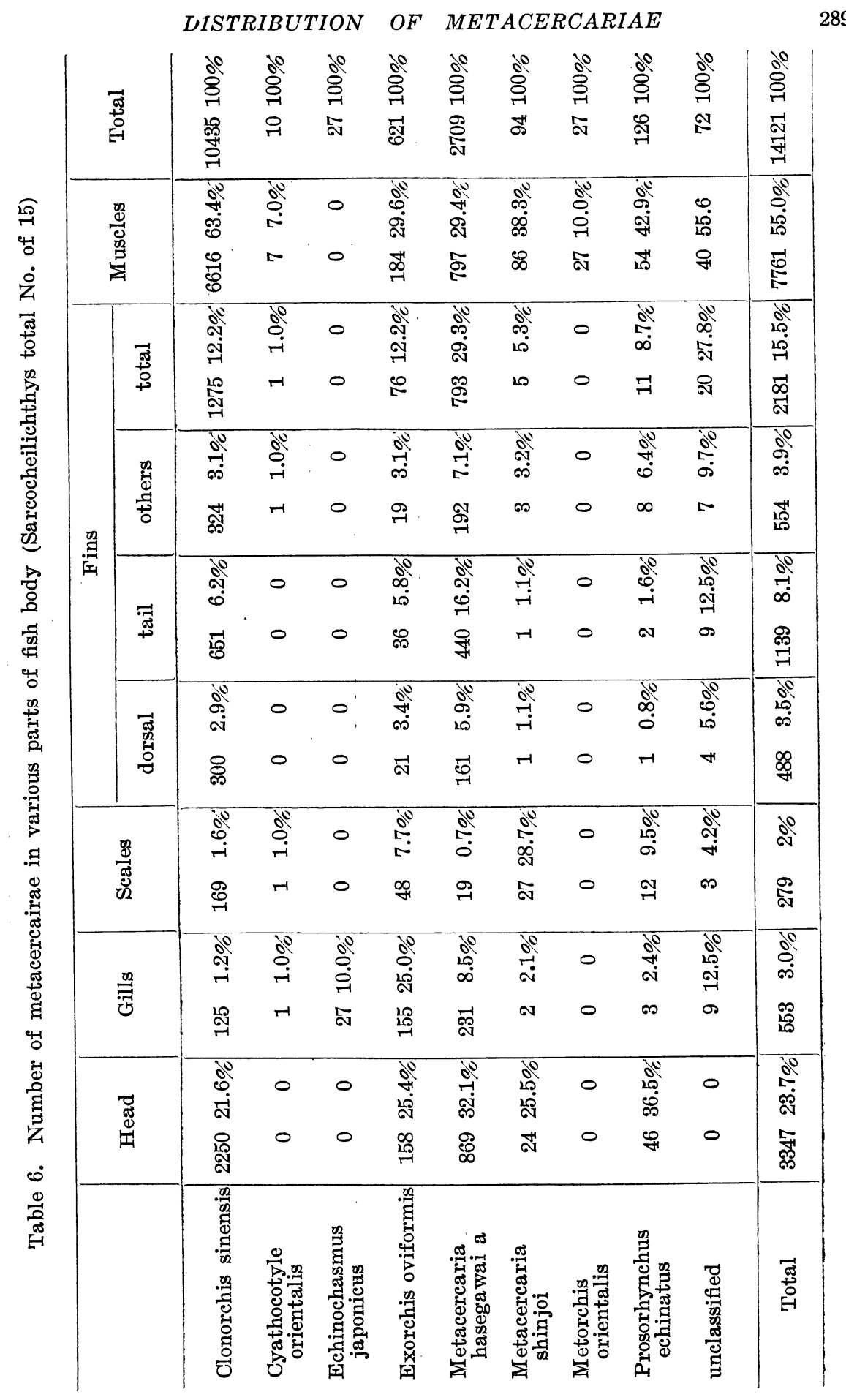




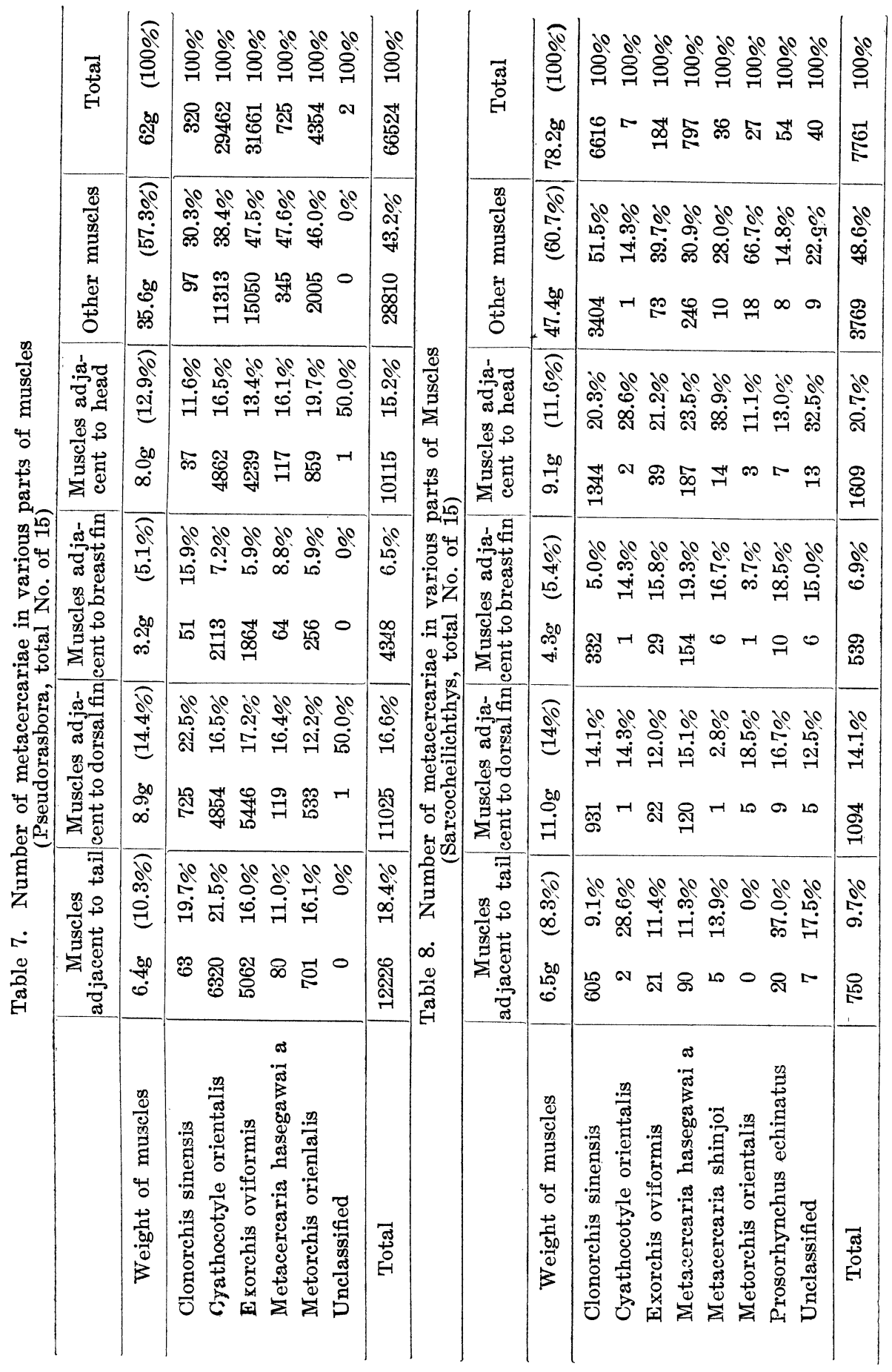




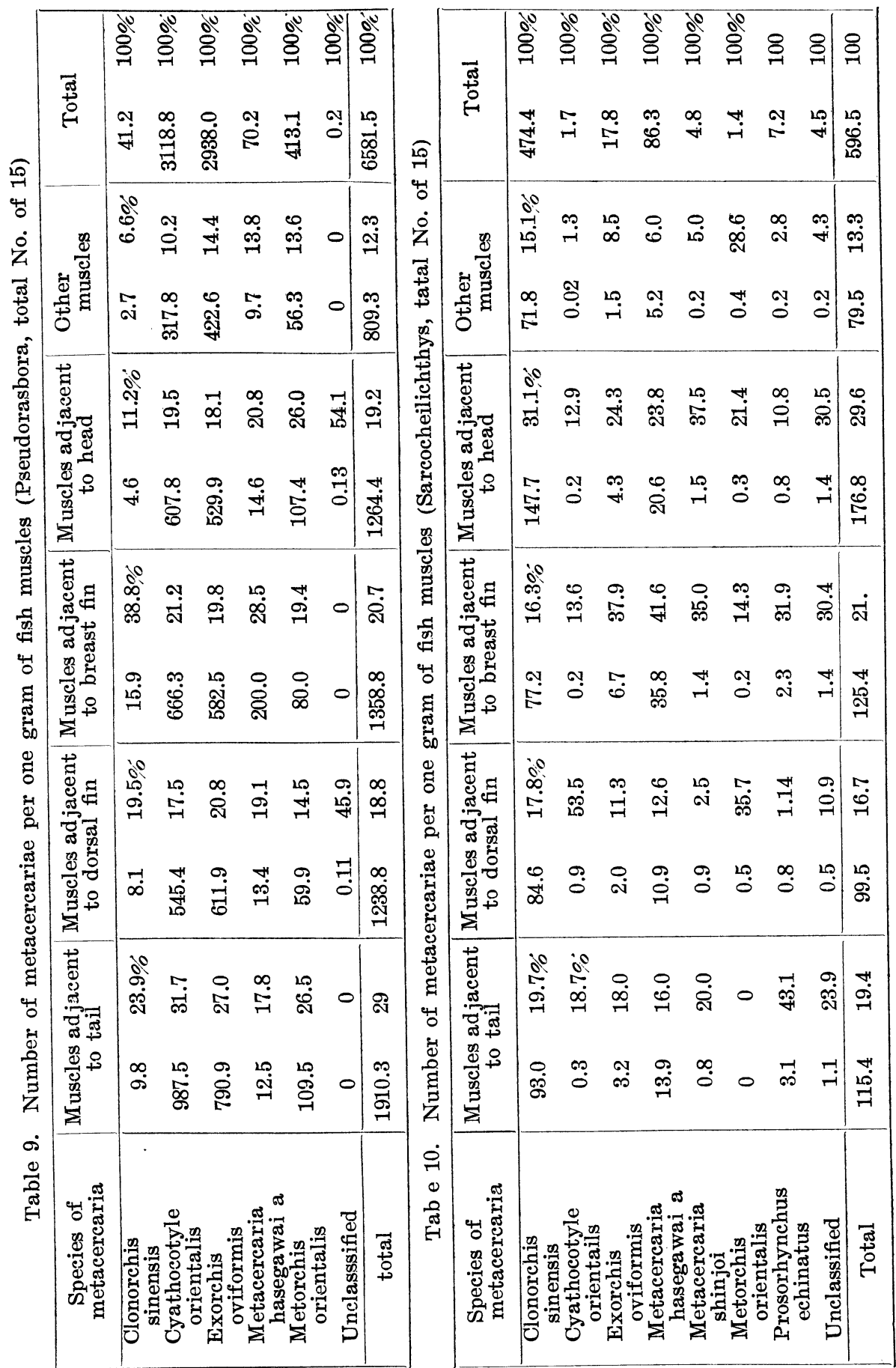


Table 11. Number of Clonorchis sinensis in various parts of fish body

\begin{tabular}{|c|c|c|c|c|c|c|c|c|}
\hline Author & $\begin{array}{l}\text { Name of } \\
\text { fish }\end{array}$ & 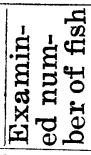 & 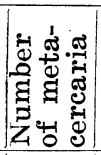 & \multicolumn{2}{|c|}{$\begin{array}{l}\text { Number of } \\
\text { metacercaria } \\
\text { in head }\end{array}$} & \multicolumn{2}{|c|}{$\begin{array}{l}\text { Number of } \\
\text { metacercaria } \\
\text { in muscles }\end{array}$} & Remark \\
\hline $\begin{array}{l}\text { Hisayama } \\
(1938)\end{array}$ & $\begin{array}{l}\text { Pseudoras- } \\
\text { bora parva }\end{array}$ & 239 & 153056 & 30402 & $19.9 \%$ & 78772 & $51.5 \%$ & natural int. \\
\hline Hsü (1939) & ” & 1 & 351 & 58 & $16.5 \%$ & 284 & $80.9 \%$ & experimental \\
\hline Kajimi $_{\text {Tajima }}(1940)$ & $"$ & 1 & 1715 & 155 & $9 \%$ & 1328 & $77.4 \%$ & $"$ \\
\hline $\begin{array}{l}\text { Komiya } \\
\text { Murase }\end{array}$ & " & 15 & 364 & 26 & $7.1 \%$ & 320 & $87.9 \%$ & Natural inf. \\
\hline Ibid $(")$, & $\begin{array}{l}\text { Sarcochilichys } \\
\text { sinensis }\end{array}$ & 15 & 10435 & 2250 & $21.6 \%$ & 6616 & $63.4 \%$ & $"$ \\
\hline
\end{tabular}

